\title{
PAŠATTİROŠI AUDUMI: KAS TIE IR UN KĀPĒC TĀDI NEPIECIEŠAMI?
}

\author{
RAIVIS EGLĪTIS ${ }^{1}$, GUNDARS MEŽINSKIS ${ }^{2 *}$, IEVA BUIĶE ${ }^{3}$ \\ ${ }^{1-3}$ Silikātu materiālu institūts, Rīgas Tehniskā universitāte, Latvija
}

Kopsavilkums. Pašattīroši audumi ir tekstilmateriāli, kuriem piemīt spēja ārēju vides faktoru iedarbībā atbrīvot savu virsmu no dažādiem piesārṇojumiem. Šādi audumi l̦auj samazināt ūdens un enerǵijas patēriṇu, kas saistīts ar drēbju mazgāšanu, samazināt infekciju risku, pateicoties to biocīdām īpašībām, kā arī pasargā cilvēkus no UV starojuma. Papildus tam šādus audumus arī būtu grūtāk saslapināt; tas mūsdienu mitrajā klimatā samazinātu diskomfortu no salijušām drēbēm. Šādus efektus pašattīroši audumi iegūtu ar tādiem mehānismiem kā fotokatalīze un superhidrofobitāte. Lai audumi iegūtu augstāk minētās īpašības, piemērotākie ir $\mathrm{ZnO}$ un $\mathrm{TiO}_{2}$ nanodaḷiṇu veidotie pārklājumi. Savukārt pārklājumu ieguvei jāizmanto sola-gēla metode, kas sniedz iespēju izveidot homogēnus pārklājumus pie temperatūrām, kuras iztur organiskas dabas materiāli. Kopš 2011. gada ar šādu audumu izstrādi ir nodarbojies Rīgas Tehniskās universitātes Dizaina tehnoloğiju institūts. Kopš 2016. gada ar šādiem pārklājumiem nodarbojas arī Rīgas Tehniskās universitātes Silikātu materiālu institūtā. Izmantojot savas gadu desmitu laikā iegūtās zināšanas sola-gēla tehnologijā un nanostrukturētu pārklājumu ieguvē, sekmīgi uzsākti pētījumi rūpnieciski izmantojamu tehnoloğiju izstrādei kokvilnas audumiem.

Atslēgas vārdi - pašattīroši audumi, sola-gēla metode, $\mathrm{TiO}_{2}, \mathrm{ZnO}$.

\section{Ievads}

Pētījumi pašattīrošu audumu izstrādē uzskatāmi par mūsdienīgiem un aktuāliem, jo veiksmīga šādu audumu izstrāde ḷautu atrisināt vairākas problēmas, kas tuvākajos gados kḷūs arvien aktuālākas. Pirmkārt, tas ir laika trūkums ikdienā; to varētu atrisināt audumi ar pašattīrošām

* Korespondējošais autors.

E-pasts: gundars.mezinskis@rtu.lv 
īpašībām. Samazinot laiku, kas tiek patērēts mazgājot drēbes, samazinātos arī ūdens un enerǵijas patērinšs. Otrkārt, mūsdienās arvien vairāk baktēriju kḷūst imūnas pret antibiotikām. Tas nozīmē, ka ir jāmeklē jauni veidi kā samazināt infekciju risku [1]. Pašattīrošiem audumiem, kas modificēti ar specifiskiem nanodaḷinu pārklājumiem, piemistu arī biocīdas īpašibas, kas l̦autu samazināt infekciju risku. Treškārt, šādi audumi l̦auj pasargāt cilvēkus no UV starojuma kaitīgās ietekmes, kas, gadiem ejot, pastiprinās [2], [3]. UV starojums iedalāms 3 kategorijās: UVA (400-320 nm), UVB (320-280 nm) un UVC (280-100 nm). No šiem visbīstamākais cilvēkam ir UVB starojums, kas var izraisīt tādas slimības kā melanomu [2].

Audumu pārklājumi iedalās pasīvajos un aktīvajos. Pasīvie pārklājumi ir tie, kas pasīvi veic kādu funkciju, piemēram, piešksir krāsu vai ugunsizturību. Aktīvie pārklājumi ir spējīgi reagèt uz apkārtējās vides izmainām. Pie aktīvajiem pārklājumiem pieskaita pašattīrošus pārklājumus, kas darbojas gaismas ietekmē [4]. Aktīvu pārklājumu iegūšanai izmanto dažādas tehnologijas: mikroiekapsulēšana, plazmas tehnoloǵijas, nanotehnoloǵijas, kā arī sola-gēla tehnologija [4].

\section{Pašattīrošu audumu vēsture}

Audumi, kas būtu noturīgi pret baktēriju un mikroorganismu kolonizāciju, kā arī pret netīrumiem ar relatīvi vienkāršām metodēm tika veidoti jau ap Otrā pasaules kara laiku. Kā piemēru var minēt telšu brezenta audumu, kas tika piesūcināts ar k,imikālijām, lai tas nesāktu bojāties un lai uz tā neattīstītos mikroorganismi. Taču šādi audumi bija ar nepatīkamu aromātu un l,oti stīvi, kas tos padarīja nepiemērotus lietošanai ikdienas apgèèrbā [5], [6].

Turpmākajos gados tika veikti eksperimenti, kas balstīti uz kokvilnas auduma šķiedru modificēšanu ar dažādām k̦imikālijām (acetilēšana, cianoetilēšana), taču tie netika ieviesti ražošanā, pateicoties metožu dārgajām izmaksām. Sintētiski radītie audumi, kas kḷuva arvien populārāki, šādu ideju padarīja vēl neizdevīgāku [5].

Attīstoties nanotehnologijām, pašattīroši audumi ieguva otru elpu un mūsdienās ir jau komerciāli pieejami audumi ar superhidrofobām īpašībām, kā arī nemitīgi tiek veikti pētījumi šādu audumu tālākai attīstībai.

\section{A. Pašattīrošu audumu izveide pasaulē}

Pašattīrošu audumu izgatavošanai var tikt izmantotas dažāda veida nanodaḷinas: $\mathrm{ZnO}$ [7], $\mathrm{TiO}_{2}$ [8], $\mathrm{Cu}_{2} \mathrm{O}$ [9], $\mathrm{CuO}$ [10], $\mathrm{Ag}_{2} \mathrm{O}$ [11], $\mathrm{SiO}_{2}$ [12], $\mathrm{Ag}$ [5], utt. No nanodaḷinuu veidiem vispopulārākās ir $\mathrm{ZnO}$ un $\mathrm{TiO}_{2}$ nanodaḷin,as. $\mathrm{TiO}_{2}$ un $\mathrm{ZnO}$ nanodalıinām piemīt unikālas optiskās, fotokatalītiskās, 
hidrofīlas īpašības. Tas padara šīs nanodaḷinas piemērotas izpētei dažādās jomās, piemēram, pašattīrošajos materiālos, antibakteriālos līdzekl’os, UV aizsargmateriālos, ūdens un gaisa attīrīšanā, gāzes sensoros, augstas efektivitātes saules šūnās un citās jomās [13].

$\mathrm{TiO}_{2}$ nanodaḷinas galvenokārt tiek sintezētas ar sola-gēla metodi, taču tiek izmantotas arī citas metodes. ZnO nanodaḷinu sintēzei arī izmanto sola-gēla metodi, taču bieži izmanto arī citas metodes, piemēram, hidrotermālo sintēzi.

Nanodaḷinu uznešana uz auduma var notikt in situ un ex situ. Vairums nanodaḷiņu iegūšanas procesu notiek ex situ: nanodaḷiņas tiek sintezētas atsevišķi un tad uznestas uz auduma. Galvenā šīs metodes problēma ir tā, ka norit nanodaḷiņu aglomerācija, kas ierobežo nanodalı̣nu izkliedi pa auduma šķiedru virsmu. Šādos gadījumos kā stabilizatorus var izmantot lielmolekulārus savienojumus, taču to klātbūtne uz auduma var ietekmēt rezultējošās fotokatalītiskās īpašības [7]. In situ sintēzē nanodaḷinas tiek sintezētas šḳīdumā, kurā tiek iemērkts audums, līdz ar to daḷinas uzreiz pēc to izveidošanās var nonākt uz auduma. Šîs metodes trūkums ir tas, ka nanodalı̣nu sintēzes procesu parametru nelielas izmainas var novest gan pie daḷinu aglomerācijas, gan pie dažādas nanodaḷinu morfoloǵijas izveides. Tas savukārt var novest pie nanodạ̦inu izveides ar atšķirīgām optiskajām, antimikrobiālajām, katalīitiskajām u. c. īpašībām [7].

Vienu no pirmajām publikācijām par anatāza nanodaḷinu uznešanu uz kokvilnas publicēja W. Daoud et al. 2004. gadā [14]. Pēc tam publicēti vairāki raksti, kas apskata anatāza nanodaḷinu uznešanu (galvenokārt uz kokvilnas), lai gan tika veikti pētījumi arī vilnas [15], [16] un sintētisko šķiedru modificēšanā [17]. Par spīti tam, ka šajā jomā strādā daudzi zinātnieki no visas pasaules, nanodaḷiṇu sintēze principā ir nemainīga. Anatāza nanodalinnas tiek galvenokārt pētītas tāpēc, ka tās var vienlaicīgi samazināt UV caurlaidību un piešķirt antibakteriālas īpašības [17]. Nanodaḷiņu sasaistes ar kokvilnu uzlabošanai zinātniskajos darbos izmanto dažādas priekšapstrādes metodes kokvilnas modifikācijai: apstarošanu ar UV gaismu [18], [19], oksidāciju $\mathrm{KMnO}_{4}$ šḳīdumā [15], tīrīšanu ar plazmu [18], ķīmisku modifikāciju ar skābēm [20], [21] un aldehīdiem [22] un mazgāšanu [23]. Mazgāšana ir populārākais priekšapstrādes veids.

Jaunākajos pētījumos, ko publicējis $M$. Abid et al., anatāza nanodalinnas iegūtas, izmantojot titāna prekursora hidrotermālu apstrādi bez iepriekšējas hidrolīzes [24]. Šādi iegūtie pārklājumi sastāv no 10-14 nm daḷinām. Pārklājumiem bija nelielas (apmēram $100 \mathrm{~nm}$ ) platas plaisas, kurām, nemot vērā baktēriju izmērus, nevajadzētu ietekmēt antibakteriālās īpašības.

Pirmie darbi, kuros kokvilnas audumi tika modificēti ar $\mathrm{ZnO}$ nanodaḷinām, tika publicēti 2009. gadā. $O$. V. Abramov et al. publicēja rakstu, 


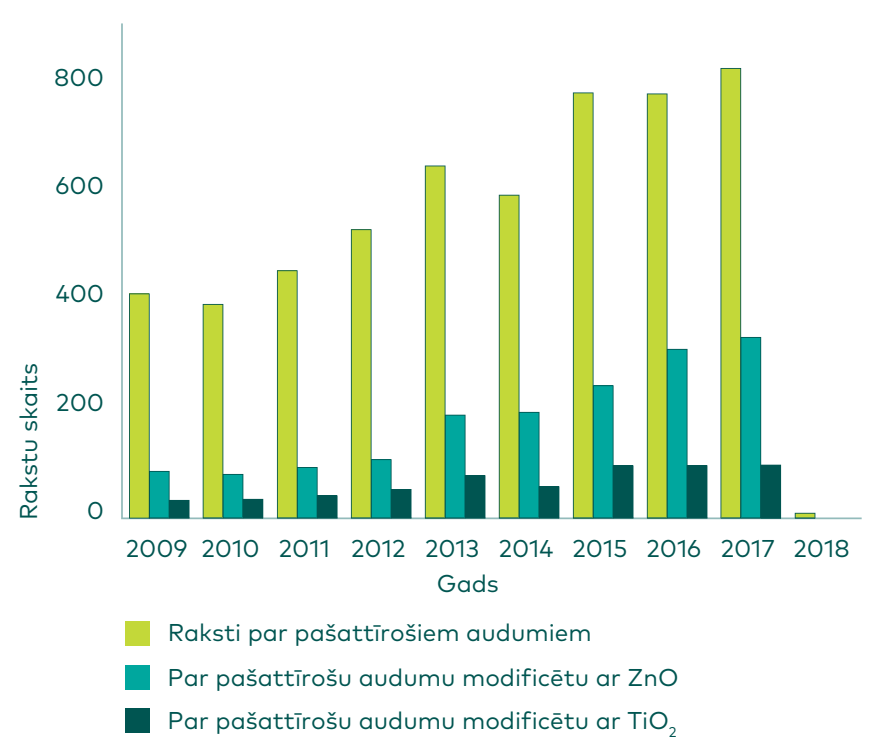

Pašattīroši audumi: kas tie ir un kāpēc tādi nepieciešami?

1. att. Publikāciju par pašattīrošiem audumiem skaits Science Direct datubāzē 2009.-2017.g.

kurā uz auduma ar sonokīmisku metodi ieguva $\mathrm{ZnO}$ un CuO pārklājumus [25]. Šādu pārklājumu iegūšanai ir tikušas izmantotas arī solagēla tehnologiija, slāṇa pēc slāṇa (layer-by-layer) metode [26] un pašsakārtošanās (self-assembly).

2017. gadā pētījumi par šādi modificētiem audumiem vēl joprojām bija aktuāli. ScienceDirect mājaslapā katru gadu tiek publicēti simtiem rakstu, kas veltīti pašattīrošiem audumiem, un ikgadējais rakstu skaits turpina pieaugt. No šiem rakstiem kopš 2013. gada vairāk kā puse ir veltìta pašattīrošiem audumiem, kas iegūti izmantojot $\mathrm{ZnO}$ vai $\operatorname{arī~} \mathrm{TiO}_{2}$.

\section{B. Poliestera audumi ar $\mathrm{TiO}_{2}$ un $\mathrm{ZnO}$ pārklājumu}

Pagājušā gadsmita sešdesmitajos gados parādījās interese par lētākām un pārstrādājamām sintētiskajām šķiedrām, piemēram, poliestera šķiedrām. To ražošanas un pieprasījuma apjomi strauji pieauga, un tādējādi dabiskās šķiedras zaudēja lielu dalıu tirgus [27].

Mūsdienās $72 \%$ Eiropas tirgus aizṇem tieši sintētiskie audumi un tekstilpreces. Poliesteris polietilēnteraftalāts (PET) ieṇem vadošo pozīciju starp visām sintētiskajām šksiedrām. Salīdzinot dabiskās šķiedras ar PET šķiedrām, ir viegli iegūt PET šķiedras ar kontrolējamām īpašībām, piemēram, elastības moduli, izturību, stiepes izturību, izmēra stabilitāti pie temperatūras izmaiṇām, nodilumizturību, izturību pret saules gaismu, skābēm un balinātājiem un virkni citām 
īpašībām [28], [29]. Poliestera šķiedras neburzās un ir izturīgas pret mazgāšanu, tāpēc tās tiek plaši izmantotas sadzīvē dažādās jomās, piemēram, mājas tekstilā, apgeērbos, paklājos, automobiḷ audumos u. c. No otras puses, tās ir ārkārtīgi hidrofobas (nepolāras) šksiedras; tā tas ir benzola gredzena un $-\mathrm{CH}_{2} \mathrm{CH}_{2}$ - grupu klātbūtnes, kā arī hidrofîlu funkcionālo grupu trūkuma dēḷ. Poliesteris ir kristāliska šḳiedra, kas sastāv no blīvi sapakotām, sakārtotām polimēra molekulām. Tā kā poliesterim nav polāro funkcionālo grupu, tās spēj labi veidot ūdeṇraža saites ar citām molekulām [29]. Tomēr šķiedru hidrofobā daba izraisa arī nevēlamas īpašības: statiskā elektriskā lādiṇa uzkrāšanos, vieglu smilšu un augsnes piesaisti [30].

Šobrīd globālās tendences tekstilrūpniecībā ir daudzfunkcionāli un "gudri" audumiem. Papildus tādām īpašībām kā modernums un ērtums vēl tiek prasītas pašattīrošas, antibakteriālas un UV staru aizsargājošas īpašības. Jaunajām tehnoloǵijām jāatbilst ne tikai funkcionalitātei un efektivitātei, bet arī vides un ekonomikas prasībām [31].

Tekstilizstrādājumu virsmas apstrādei tiek izmantotas dažādas metodes. Šobrīd lielu popularitāti un interesi ir ieguvusi apstrāde tieši ar $\mathrm{TiO}_{2}$ un $\mathrm{ZnO}$ nanodalināām. Šìm nanodaḷinām piemīt optiskas, fotokatalìtiskas un hidrofīlas īpašības, kas padara tās piemērotas pielietošanai dažādās jomās, piemēram, pašatīrošajos materiālos, antibakteriālos līdzekḷıs, UV aizsargmateriālos, ūdens un gaisa attīī̌šanā, gāzes sensoros, augstas efektivitātes fotoelementiem jeb saules elementiem un citās [13], [27].

Lai uznestu $\mathrm{TiO}_{2}$ un $\mathrm{ZnO}$ nanodaḷinas uz poliestera auduma, tiek izmantotas dažādas metodes, piemēram, pirms nanodaḷiņu uzklāšanas, poliestera šķiedras tika apstrādātas ar ultraskaṇas aktivētu sārmu hidrolīzi [30], izmantota iemērkšanas metode uz plazmas modificētām poliesteru un poliamīdu šḳiedrām [32]; neapstrādātām poliestera šķiedrām uzklātas $\mathrm{TiO}_{2}$ nanodaḷiṇas, kas modificētas ar (3-aminopropyi)-trimetoksisilānu [33], kā arī sonoḳīmiskā metode [34].

Sonoķīmiskā metode ir efektīva metode nanomateriālu sintēzē, jo var iegūt nanodalinas, nelietojot augstas temperatūras un spiedienu, nav nepieciešami arī ilgi reakcijas laiki. Sonoḳimija nodarbojas ar k̦īmisko reakciju realizāciju apstākḷos, kas nodrošina reaǵējošo vielu maisījuma apstrādi spēcīgā ultraskaṇas laukā (20 KHz - 10 MHz). Fizikālā parādība, kas ir sonokīimisko procesu pamatā, ir saistīta ar akustisko kavitāciju. Galvenie procesi, kas norit ultraskaṇas apstrādes laikā, ir nanoizmēra burbuḷu veidošanās šḳidrumā, to augšana un sabrukums. Burbuḷu sabrukuma laikā tiek sasniegta 500-25000 K temperatūra. Šādas temperatūras ir pietiekamas, lai sarautu šķīdumā izšķīdušo vielu ķīmiskās saites. Literatūrā atrodamās ziṇas liecina, ka ultraskaṇas apstrādes laikā izveidojušās nanoizmēra nanodalı̣nas veido homogēnu pārklājumu uz poliestera auduma šksiedrām [35]. 
Parasti starp neorganiskām dal̦inām un polimērmateriālu nenotiek mijiedarbība, tādēl ar nanodaḷṇām apstrādātā virsma nav noturīga, it īpaši pret mazgāšanu. Šì iemesla dēl tāpēc daudzi pētījumi veltīti tieši dal̦iṇu stabilizēšanai uz tekstilmateriāla. Dal̦iṇu stabilizēšanai uz virsmas ir nepieciešami daudzpakāpju procesi, piemēram, funkcionalizācija, gala apstrāde, žāvēšana, cietināšana, u. c. Šobrīd virmas stabilizēšanai vēl ir pārāk augstas izmaksas un tā ir pārāk laikietilpīga, lai varētu to ieviest plašā produktu ražošanā. Piemēram, poliestera virsmas apstrādei var izmantot apstarošanu ar UV gaismu, kas veicina dažu radikāḷu grupu veidošanos, kas saistās ar neorganiskajām nanodaḷinām; var izmantot arī polisiloksāna šksīdumu, kas ne tikai saista dal̦in,as, bet arī nodrošina antibakteriālas īpašības [36]; vēl var izmantot askorbīnskābi, kas ir ne tikai dabisks antioksidants, bet arī spontāns, reducējošs aǵents, kas novērš daļiņu oksidēšanos [37].

\section{Pašattīrošu audumu izveide Latvijā}

Rīgas Tehniskās universitātes Dizaina tehnologiju institūta darbinieki kopš 2011. g. ir mēǵinājuši modificēt kokvilnas audumu ar Zn un Si saturošiem savienojumiem [38]-[45]. Izmantojot sola-gēla tehnologiju, apstrādāja kokvilnas audums, galvenokārt ar cinka acetāta dihidrātu (divās publikācijās arī ar cinka sultātu [39], [40]) un tetraetoksisilānu. Iegūtie pārklājumi sākotnēji pētīti ar skenējošās elektronu mikroskopijas (SEM) un rentgenstaru energijas dispersijas spektroskopijas palīdzību, lai noskaidrotu to morfologiju un pārklājuma k̦īmisko sastāvu [38][41]. Noskaidrots, ka ar sistēmas $\mathrm{ZnO}-\mathrm{SiO}_{2}$ pārklājumiem, kas iegūti pēc iepriekšējos darbos aprakstītajām sola ieguves metodēm [38-41], ir iespējams uzlabot UV aizsardzības spēju kokvilnas audumam [42], kā arī iegūt hidrofobus [43] un antimikrobiālus kokvilnas audumus [44].

Minētajos pētījumos tika veikta amorfu pārklājumu iegūšana hidrofobitātes palielināšanai [43]. Taču, nevienā no publikācijām nav apskatīta fotokatalītiskā aktivitāte, kas varētu piemist audumiem, pateicoties iespējamajai ZnO klātbūtnei, kā arī nav pieejami rentgenstaru difrakcijas dati, kas parādītu uz šksiedru virsmas iegūtā pārklājuma mineralogisko sastāvu. Lai gan tiek uzsvērts, ka iegūti ZnO nanodaḷinu pārklājumi, nav rezultātu, kas pierādītu ZnO nanodaḷiṇu klātbūtni [38-45]. Visos pieejamajos darbos tika izmantota viena sola-gēla sintēzes shēma, kas balstās uz tetraetoksisilāna hidrolīzi spirta šksīdumos. Tā kā izmantotais kokvilnas audums ar veidoto pārklājumu nevar tikt ilgstoši apstrādāts temperatūrās, kas augstākas par 100-120 드. izmantotā sintēzes shēma l̦āva iegūt tikai amorfus, polimērveida pārklājumus. Daḷingveida solu ieguve ūdens šḳīdumos l̦autu iegūt kristālisku oksīdu nanodaḷiṇu veidotus pārklājumus ar potenciāli labākām īpašībām un līdzīgu noturību pret mazgāšanu. Šeit arī der pieminēt, ka ar sola-gēla metodi ir iespējams 
uz auduma iegūt pārklājumus, kas sastāv no kristāliskām $\mathrm{ZnO}$ un $\mathrm{TiO}_{2}$ nanodaḷin,ām [46], [47]. Literatūrā ir pieejamie dati liecina, ka kokvilnas pārklājumiem, kas veidoti no amorfa $\mathrm{SiO}_{2}$, piemīt arī lototi labas hidrofobās ipašǐbas, kas Zn prekursora lietošanu padara lieku [48], [49].

Publicētie rentgenstaru enerǵijas dispersijas spektroskopijas analīžu rezultāti arī parāda, ka pārklājumi satur F- jonus [38]-[41], [44]. Tas liecina par fluorīdu, tai skaitā iespējamu fluorūden,ražskābes klātbūtni. Tā nav vēlama materiālos, kas ir tiešā kontaktā ar cilvēka ādu. Pēc darbos publicētā sintēzes apraksta var spriest, ka šo problēmu varētu vienkārši novērst, fluorūden,ražskābes vietā lietojot hlorūden̦ražskābi vai slāpekḷskābi.

Vēl jāatzīmē nesen publicēts darbs, kas veltìts kokvilnas un linu šķiedru modifikācijai [45]. Šī raksta autori nepiekrīt apgalvojumam, ka skenējošās elektronu mikroskopijas (SEM) rezultāti liecina par pārklāto šķiedru nanolīmeña raupjainību. Publicēto SEM attēlu palielinājums (2.-5. att. [50]) padara šādu apgalvojumu neiespējamu.

Jāatzīmē Dizaina tehnoloğiju institūtā veiktie pētījumi, kas raksturo tekstilmateriālu parametrus [38]-[41], [50]. Atzinību pelna arī veiktie mikrobiologiskie testi [44], kas parāda, ka apstrādātiem audumiem var būt arī biocīda iedarbība.

\section{Mūsdienu pašattīrošu audumu darbības mehānismi}

Par materiāla pašattīî̌šanos sauc tā spēju mitruma vai ūdens klātbūtnē pašattīrīties, atgrūžot, vai fizikāli ķīmisku procesu rezultātā sadalot netīrumus, kas nokḷuvuši uz tā virsmas. Pašattīî̌šanās process norisinās pateicoties materiāla virsmas mikro- un nanostruktūras īpatnībām un tā mijiedarbībai ar ārējiem vides faktoriem. Šì spēja parasti izpaužas kā viena vai vairāku materiālam esošu īpašību kombinācija. Galvenie pašattīrīšanos vadošie mehānismi ir fotokatalīze, superhidrofobitāte un superhidrofilitāte. Pašattīrošo audumu darbības mehānismi balstās uz fotokatalīzi, superhidrofobitāti vai arī abiem mehānismiem reizē [6].

\section{A. Fotokatalīze}

Svarīga īpašība pašattīrošiem materiāliem ir fotokatalītiskā aktivitāte [23]. Definīcija šim procesam ir vienkārša - to var aprakstīt šādi: gaismai krītot uz pusvadītāja materiālu, fotoni, kam ir pietiekoši liela enerğija, izraisa elektrona pāreju no valences un vadāmības zonu, atstājot aiz sevis caurumu. Lielākā dạ̣a šādu elektronu-caurumu pāru (kas fizikā tiek apskatīti kā kvazidaḷinas ar nosaukumu eksitoni) lielākoties 


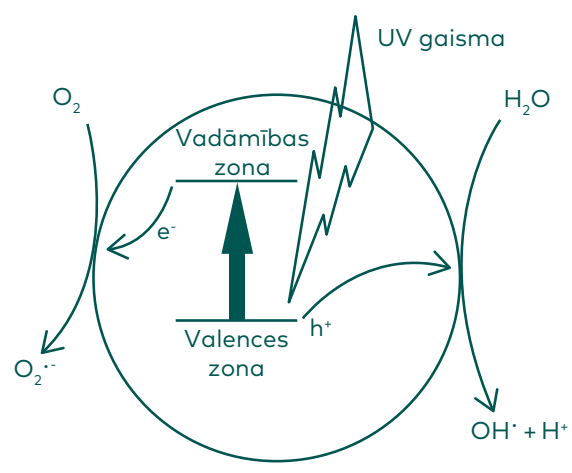

2. att. Fotokatalīzes darbības princips [51].

rekombinējas. Taču dal̦a no šiem eksitoniem var mijiedarboties ar uz pusvadītāja dal̦iñas virsmas esošajām ūdens un skābekḷa molekulām, un tā rezultātā rodas reaktīvi skābekḷ radikāḷi (reactive oxygen species jeb ROS). ROS ir spējīgi iesaistīties radikālu reakcijās ar organiskām molekulām. Rezultāts ir šo organisko molekulu sadalī̌anās, iegūstot atsevišku elementu oksīdus $\left(\mathrm{CO}_{2}, \mathrm{SO}_{2}, \mathrm{H}_{2} \mathrm{O}, \mathrm{NO}_{\mathrm{x}}\right.$, utt.). Šāda veida darbības mehānisms pašattīrošām virsmām parādīts 2. att. [51].

Fotokatalītiskā aktivitāte ir viena no mūsdienās visplašāk pētītākajām materiālu īpašībām. Galvenie materiāli, kas tiek pētīti šajā jomā ir ZnO un $\mathrm{TiO}_{2}$, galvenokārt cincīta un anatāza kristāliskajās fāzēs. No šiem abiem materiāliem anatāzs izceḷas ar savām lieliskajām fotokatalītiskajām īpašībām. Diemžēl anatāza aizliegtās zonas platums ir 3,2 eV. Tas nozīmē, ka tā fotokatalītiskās īpašības izpaužas tikai apstarojot to ar UV gaismu. Līdzīga problēma ir ZnO. Viens veids kā zinātnieki cenšas šo problēmu risināt ir šo oksīdu dopēšana jeb legēěšna ar citiem katjoniem, kas šo oksīdu aizliegtajā zonā ieviestu donor- vai akceptorlīmen,us, kas samazinātu samazinātu aizliegtās zonas platumu materiālam. Problēma ar šādu legéěanu ir stabilitāte un Red/Oks potenciāla samazinājums, kas rodas, ievedot papildus enerǵijas līmen,us aizliegtajā zonā. Pārlieku sašaurinot aizliegto zonu, var rasties situācija, ka materiāla Red/Oks potenciāls ir pārāk mazs, lai spētu radīt radikāḷus. Līdz ar to pazūd fotokatalītiskā aktivitāte [52].

Stabilitāte arī ir problēma, it īpaši anatāza gadījumā. Iemesls tam ir tas, ka anatāzs ir metastabila fāze. No visām $\mathrm{TiO}_{2}$ kristāliskajām modifikācijām vienīgā, kas ir stabila istabas temperatūrā, ir rutils. Bet rutilam ir daudz sliktākas fotokatalītiskās īpašības, salīdzinot ar anatāzu [53].

\section{B. Superhidrofobitāte}

Jebkurš šḳidrums veidos pilienu, nonākot kontaktā ar kādu virsmu. Leṇki, ko piliens veido ar gludu virsmu, sauc par slapināšanas leṇksi. Tā noteikšana parādīta 3 . att. Ja šksidrums, kas tiek pilināts uz virsmas, ir 


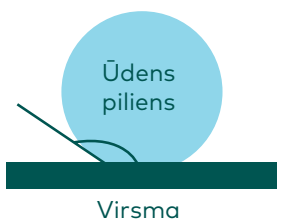

b

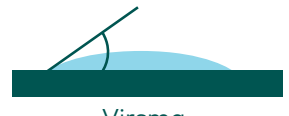

3. att. Virsmas slapināšana hidrofobu un hidrofïlu virsmu gadījumā.

ūdens un šis leṇksis ir lielāks par $150^{\circ}$, tad šãdu virsmu sauc par superhidrofobu. Dabā ir sastopami daudzi augi, kuru lapām piemīt šāda īpašība. Plaši izmantots piemērs ir lotosa auga lapa, uz kuras nonākušais ùdens savel̦as pilienos un noslīd nost [54].

Šādu efektu materiāli iegūst, pateicoties to virsmas struktūrai. Lotosa lapas virsma ir klāta ar mikro- un nanoizmēra struktūrām. Šìs struktūras padara ūdens savelšanos pilienā par enerḡètiski izdevīgāko stāvokli.

Pilienam atrodoties uz superhidrofobas virsmas, tas var būt 2 savstarpēji konkurējošos stāvokḷos: Kesija (Cassie) stāvoklī un Venzela (Wenzel) stāvoklī. Atškiirība starp šiem 2 stāvokḷiem parādīta 4. att.

Atšķirība starp abiem modeliem ir vienkārša. Kesija modelī piliena virsma atbalstās pret struktūrām, arī zem piliena ir gaisa kabatas, un šķietamais slapināšanas leṇksis ir lielāks. Venzela modelī piliena virsma ir pārdurta, un spraugas starp virsmas struktūrām ir aizpildītas ar ūdeni. Piliens it kā "iegrimst" virsmā, un šķietamais slapināšanas leṇķis ir mazāks nekā, ja piliens atrastos uz strukturētas virsmas [54].

a

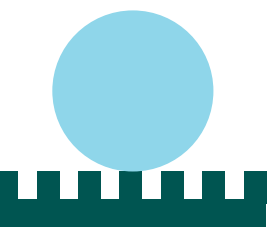

b

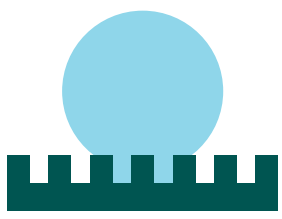

4. att. Superhidrofobu virsmu

a) Kesija modelis; b) Venzela modelis [54].

\section{B. Superhidrofilitāte}

Superhidrofilitāte ir pretējs efekts superhidrofobitātei - ūdens ideāli slapina virsmu un piliens uz tās izplūst vienmērīgā plēvītē. Ja virsma, uz kuras atrodas šāds pārklājums, ir slīpa, tad ūdens notecēs nost, vienlaicīgi noṇemot uz virsmas esošos putekḷus vai citas cietās daḷiṇas. Šāda situācija ir parādīta 5. att. Savukārt audumiem šāds efekts ir nevēlams vienkāršu iemeslu dēḷ: superhidrofīls audums, nonākot kontaktā ar ūdeni, acumirklī saslapinātos (tīra kokvilna tā arī uzvedas) un to uzsūktu. Bet superhidrofobs audums ilgstoši paliktu sauss, arī nonākot saskarsmē ar ūdeni. 


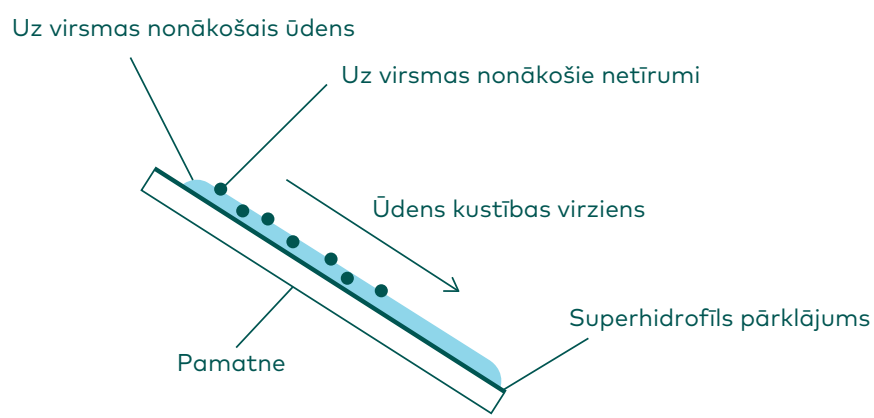

5. att. Superhidrofīlas virsmas pašattīrošo īpašību princips [6].

\section{Silikātu materiālu institūtā veiktie pētījumi pašattīrošu audumu izstrādē}

2015. g. rudenī Rīgas Tehniskās universitātes Silikātu materiālu institūtā uzsākti pētījumi audumu modificēšanā, izmantojot nanodaḷinas. Pirmajos pētījumos veiksmīgi iegūti kokvilnas audumi, kas UV gaismā uzrādīja fotokatalītisku aktivitāti. Šie audumu bija pārklāti ar anatāza nanodalı̣nām, kas sintezētas ar zemtemperatūras sola-gēla metodi [55]. Pašlaik pētījumi tiek turpināti, veidojot arī ZnO nanodaḷinu pārklājumus uz kokvilnas, kā arī mēǵinot uzlabot anatāza nanodaḷinu pārklājumus, pakḷaujot audumu dažādām priekšapstrādes un pēcapstrādes metodēm, kas manāmi ietekmē rezultējošo fotokatalītisko aktivitāti. Papildus tiek pētīta arī sintētisko audumu modificēšana ar šādiem pārklājumiem.

Iegūtie pārklājumi piešksir audumam fotokatalītiskas īpašības un superhidrofobitāti, audumam ḷaujot atgrūst ūdeni neierobežoti ilgi no

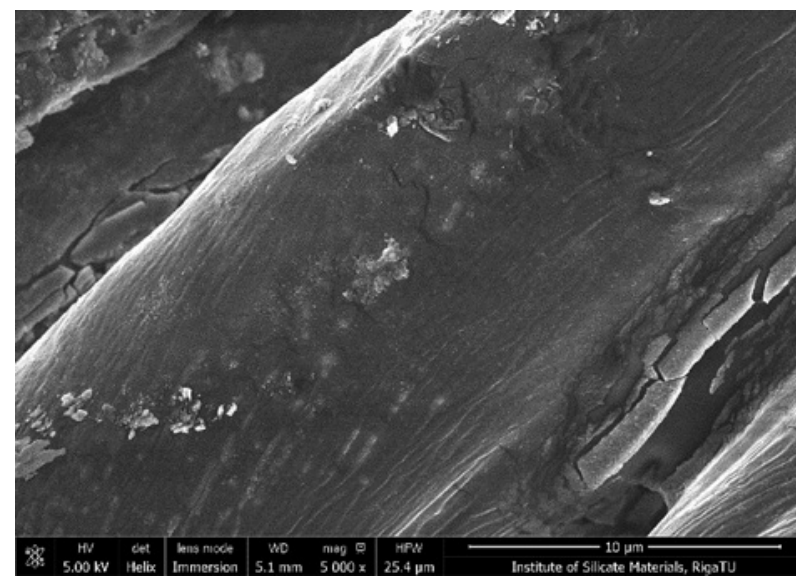

6. att. Modificētas kokvilnas šķiedras attēls, iegūts izmantojot augstas izšksirtspējas lauka emisijas skenējošo elektronu mikroskopiju. 
auduma virsmas. Tas paver iespējas aktīvās atpūtas cienītāju apgeērbu padarīt daudz grūtāk saslapināmu un grūtāk nosmērējamu. Turklāt viss ūdens, kas nonāktu uz apgérba virsmas, l̦autu notīinit uz tā esošos netīrumus.

Šajā jomā RTU Silikātu, augsttemperatūras un neorganisko nanomateriālu tehnoloǵijas katedrā izstrādāts viens bakalaura un divi maǵistra darbi.

\section{Kopsavilkums}

Pašattīroši audumi ir mūsdienās augošs zinātnes lauks, kurā publicēto rakstu skaits ar katru gadu aug. Galvenie materiāli, kas tiek izmantoti šādu audumu iegūšanai, ir $\mathrm{TiO}_{2}$ un $\mathrm{ZnO}$, un biežāk modificētais audums ir kokvilna. Pašattīroši materiāli darbojas uz 3 dažādu mehānismu pamata: superhidrofobitātes, superhidrofilitātes un fotokatalītiskās aktivitātes. No šiem 3 mehānismiem pašattīroši audumi izmanto fotokatalīzi un superhidrofobitāti.

Latvijā pašattīrošus audumus ir pētījuši mūsu kolēǵi Rīgas Tehniskās universitātes Dizaina tehnologiju institūtā. Viṇi pētīja galvenokārt Si un Zn savienojumu veidotos pārklājumus. Mēs Silikātu materiālu institūtā esam veikuši pētījumus $\mathrm{ZnO}$ un $\mathrm{TiO}_{2}$ pārklājumu iegūšanā gan uz kokvilnas, gan arī uz poliestera audumiem. Rezultāti ir prezentēti starptautiskajā konferencē Functional Materials and Nanotechnologies 2017, par šīm tēmām ir uzrakstīts bakalaura un 2 maǵistra darbi.

\section{LITERATŪRAS SARAKSTS}

[1] P. M. Hawkey, "The origins and molecular basis of antibiotic resistance," BMJ, vol. 317, no. 7159, pp. 657-660, Sep. 1998. https://doi.org/10.1136/ bmj.317.7159.657

[2] J. Allen, "Ultraviolet Radiation: How It Affects Life on Earth," earthobservatory.nasa.gov, Sep. 2, 2001. [Online]. Available: https://earthobservatory.nasa.gov/Features/UVB/. [Accessed: May 1, 2017].

[3] M. Carlowicz, "New Simulation Shows Consequences of a World Without Earth's Natural Sunscreen," nasa.gov, Mar. 18, 2009 [Online]. Available: https://www.nasa.gov/topics/earth/features/world_avoided.html. [Accessed: May 1, 2017].

[4] J. Hu, Active coatings for smart textiles. Amsterdam, the Netherlands: Woodhead Publishing, 2016.

[5] M. M. G. Fouda, "Antibacterial Modification of Textiles Using Nanotechnology," in A Search for Antibacterial Agents, Sep. 2012. https://doi. org $/ 10.5772 / 45653$ 
[6] M. F. Ashby, P. J. Farreira, and D. L. Schodek, Nanomaterials, Nanotechnologies and Design. Amsterdam, the Netherlands: Elsevier, 2009. https://doi. org/10.1016/b978-0-7506-8149-0.x0001-3

[7] D. Staneva, D. Atanasova, E. Vasileva-Tonkova, V. Lukanova, and I. Grabchev, "A cotton fabric modified with a hydrogel containing ZnO nanoparticles. Preparation and properties study," Applied Surface Science, vol. 345, pp. 72-80, Aug. 2015. https://doi.org/10.1016/j.apsusc.2015.03.141

[8] L. Lopez, W. A. Daoud, and D. Dutta, "Preparation of large scale photocatalytic $\mathrm{TiO}_{2}$ films by the sol-gel process," Surface and Coatings Technology, vol. 205, no. 2, pp. 251-257, Oct. 2010. https://doi.org/10.1016/j. surfcoat.2010.06.028

[9] H. E. Emam, A. P. Manian, B. Široká, H. Duelli, P. Merschak, B. Redl, and T. Bechtold, "Copper(I)oxide surface modified cellulose fibers-Synthesis, characterization and antimicrobial properties," Surface and Coatings Technology, vol. 254, pp. 344-351, Sep. 2014. https://doi.org/10.1016/j. surfcoat.2014.06.036

[10] I. Perelshtein, G. Applerot, N. Perkas, E. Wehrschuetz-Sigl, A. Hasmann, G. Guebitz, and A. Gedanken, "CuO-cotton nanocomposite: Formation, morphology, and antibacterial activity," Surface and Coatings Technology, vol. 204, no. 1-2, pp. 54-57, Sep. 2009. https://doi.org/10.1016/j. surfcoat.2009.06.028

[11] Y. L. Lam, C. W. Kan, and C. W. M. Yuen, "Effect of metal oxide on antimicrobial finishing of cotton fabric," BioResources, vol. 7, no. 3, pp. 39603983, 2012.

[12] B. Xu, Z. Cai, W. Wang, and F. Ge, "Preparation of superhydrophobic cotton fabrics based on $\mathrm{SiO}_{2}$ nanoparticles and $\mathrm{ZnO}$ nanorod arrays with subsequent hydrophobic modification," Surface and Coatings Technology, vol. 204, no. 9-10, pp. 1556-1561, Jan. 2010. https://doi.org/10.1016/j. surfcoat.2009.09.086

[13] R. Dastjerdi and M. Montazer, "A review on the application of inorganic nano-structured materials in the modification of textiles: Focus on antimicrobial properties," Colloids and Surfaces B: Biointerfaces, vol. 79, no. 1, pp. 5-18, Aug. 2010. https://doi.org/10.1016/j.colsurfb.2010.03.029

[14] W. A. Daoud and J. H. Xin, "Nucleation and Growth of Anatase Crystallites on Cotton Fabrics at Low Temperatures," Journal of the American Ceramic Society, vol. 87, no. 5, pp. 953-955, May 2004. https://doi. org/10.1111/j.1551-2916.2004.00953.x

[15] M. Montazer and E. Pakdel, "Functionality of nano titanium dioxide on textiles with future aspects: Focus on wool," Journal of Photochemistry and Photobiology C: Photochemistry Reviews, vol. 12, no. 4, pp. 293-303, Dec. 2011. https://doi.org/10.1016/j.jphotochemrev.2011.08.005

[16] E. Pakdel, W. A. Daoud, L. Sun, and X. Wang, "Photostability of wool fabrics coated with pure and modified $\mathrm{TiO}_{2}$ colloids," Journal of Colloid and Interface Science, vol. 440, pp. 299-309, Feb. 2015. https://doi. org/10.1016/j.jcis.2014.10.032

[17] M. Radetić, "Functionalization of textile materials with $\mathrm{TiO}_{2}$ nanoparticles," Journal of Photochemistry and Photobiology C: Photochemistry 
Reviews, vol. 16, pp. 62-76, Sep. 2013. https://doi.org/10.1016/j. jphotochemrev.2013.04.002

[18] M. I. Mejía, J. M. Marín, G. Restrepo, C. Pulgarín, E. Mielczarski, J. Mielczarski, Y. Arroyo, J.-C. Lavanchy, and J. Kiwi, "Self-cleaning modified $\mathrm{TiO}_{2}$-cotton pretreated by UVC-light $(185 \mathrm{~nm})$ and $\mathrm{RF}$-plasma in vacuum and also under atmospheric pressure," Applied Catalysis B: Environmental, vol. 91, no. 1-2, pp. 481-488, Sep. 2009. https://doi.org/10.1016/j. apcatb.2009.06.017

[19] A. Bozzi, T. Yuranova, I. Guasaquillo, D. Laub, and J. Kiwi, "Self-cleaning of modified cotton textiles by $\mathrm{TiO}_{2}$ at low temperatures under daylight irradiation," Journal of Photochemistry and Photobiology A: Chemistry, vol. 174, no. 2, pp. 156-164, Aug. 2005. https://doi.org/10.1016/j. jphotochem.2005.03.019

[20] O. Galkina, "Functional hybrid bionanomaterials based on titanium dioxide and cellulose, possessing antibacterial and drug delivery properties," licentiate thesis, Swedish University of Agricultural Sciences, Uppsala, Sweden, 2015.

[21] K. T. Meilert, D. Laub, and J. Kiwi, "Photocatalytic self-cleaning of modified cotton textiles by $\mathrm{TiO}_{2}$ clusters attached by chemical spacers," Journal of Molecular Catalysis A: Chemical, vol. 237, no. 1-2, pp. 101-108, Aug. 2005. https://doi.org/10.1016/j.molcata.2005.03.040

[22] R. N. Wijesena, N. D. Tissera, R. Perera, K. M. Nalin de Silva, and G. A. J. Amaratunga, "Slightly carbomethylated cotton supported $\mathrm{TiO}_{2}$ nanoparticles as self-cleaning fabrics," Journal of Molecular Catalysis A: Chemical, vol. 398, pp. 107-114, Mar. 2015. https://doi.org/10.1016/j. molcata.2014.11.012

[23] Kaihong Qi, Xiaowen Wang, and J. H. Xin, "Photocatalytic self-cleaning textiles based on nanocrystalline titanium dioxide," Textile Research Journal, vol. 81, no. 1, pp. 101-110, Nov. 2010. https://doi. org/10.1177/0040517510383618

[24] M. Abid, S. Bouattour, D. S. Conceição, A. M. Ferraria, L. F. Vieira Ferreira, A. M. Botelho do Rego, M. R. Vilar, and S. Boufi, "Hybrid cotton-anatase prepared under mild conditions with high photocatalytic activity under sunlight," RSC Advances, vol. 6, no. 64, pp. 58957-58969, 2016. https:// doi.org/10.1039/c6ra10806g

[25] O. V. Abramov, A. Gedanken, Y. Koltypin, N. Perkas, I. Perelshtein, E. Joyce, and T. J. Mason, "Pilot scale sonochemical coating of nanoparticles onto textiles to produce biocidal fabrics," Surface and Coatings Technology, vol. 204, no. 5, pp. 718-722, Dec. 2009. https://doi.org/10.1016/j. surfcoat.2009.09.030

[26] Ş. S. Uğur, M. Sarışık, A. H. Aktaş, M. Ç. Uçar, and E. Erden, "Modifying of Cotton Fabric Surface with Nano-ZnO Multilayer Films by Layer-byLayer Deposition Method," Nanoscale Research Letters, vol. 5, no. 7, pp. 1204-1210, May 2010. https://doi.org/10.1007/s11671-010-9627-9

[27] H. Gaminian and M. Montazer, "Enhanced Self-Cleaning Properties on Polyester Fabric Under Visible Light Through Single-Step Synthesis of Cuprous Oxide Doped Nano-TiO 2 ," Photochemistry and Photobiology, vol. 91, no. 5, pp. 1078-1087, Jul. 2015. https://doi.org/10.1111/php.12478 
[28] A. Ojstršek, K. S. Kleinschek, and D. Fakin, "Characterization of nanosized TiO2 suspensions for functional modification of polyester fabric," Surface and Coatings Technology, vol. 226, pp. 68-74, Jul. 2013. https://doi. org/10.1016/j.surfcoat.2013.03.037

[29] D. Fakin, K. Stana Kleinschek, M. Kurečič, and A. Ojstršek, "Effects of nanoTiO $-\mathrm{SiO}_{2}$ on the hydrophilicity/dyeability of polyester fabric and photostability of disperse dyes under UV irradiation," Surface and Coatings Technology, vol. 253, pp. 185-193, Aug. 2014. https://doi. org/10.1016/j.surfcoat.2014.05.035

[30] H. Gaminian and M. Montazer, "Simultaneous nano $\mathrm{TiO}_{2}$ sensitization, application and stabilization on polyester fabric using madder and $\mathrm{NaOH}$ producing enhanced self-cleaning with hydrophilic properties under visible light," Journal of Photochemistry and Photobiology A: Chemistry, vol. 332, pp. 158-166, Jan. 2017. https://doi.org/10.1016/j. jphotochem.2016.08.022

[31] D. Mihailović, Z. Šaponjić, M. Radoičić, T. Radetić, P. Jovančić, J. Nedeljković, and M. Radetić, "Functionalization of polyester fabrics with alginates and $\mathrm{TiO}_{2}$ nanoparticles," Carbohydrate Polymers, vol. 79, no. 3, pp. 526532, Feb. 2010. https://doi.org/10.1016/j.carbpol.2009.08.036

[32] M. Radetić, "Functionalization of textile materials with $\mathrm{TiO}_{2}$ nanoparticles," Journal of Photochemistry and Photobiology C: Photochemistry Reviews, vol. 16, pp. 62-76, Sep. 2013. https://doi.org/10.1016/j. jphotochemrev.2013.04.002

[33] D. Pasqui and R. Barbucci, "Synthesis, characterization and self cleaning properties of titania nanoparticles grafted on polyester fabrics," Journal of Photochemistry and Photobiology A: Chemistry, vol. 274, pp. 1-6, Jan. 2014. https://doi.org/10.1016/j.jphotochem.2013.08.017

[34] T. Harifi and M. Montazer, "A review on textile sonoprocessing: A special focus on sonosynthesis of nanomaterials on textile substrates," Ultrasonics Sonochemistry, vol. 23, pp. 1-10, Mar. 2015. https://doi.org/10.1016/j. ultsonch.2014.08.022

[35] T. Harifi and M. Montazer, "A robust super-paramagnetic $\mathrm{TiO}_{2}: \mathrm{Fe}_{3} \mathrm{O}_{4}: \mathrm{Ag}$ nanocomposite with enhanced photo and bio activities on polyester fabric via one step sonosynthesis," Ultrasonics Sonochemistry, vol. 27, pp. 543-551, Nov. 2015. https://doi.org/10.1016/j.ultsonch.2015.04.008

[36] R. Dastjerdi, M. Montazer, and S. Shahsavan, "A new method to stabilize nanoparticles on textile surfaces," Colloids and Surfaces A: Physicochemical and Engineering Aspects, vol. 345, no. 1-3, pp. 202-210, Aug. 2009. https://doi.org/10.1016/j.colsurfa.2009.05.007

[37] Z. Komeily-Nia, M. Montazer, and M. Latifi, "Synthesis of nano copper/ nylon composite using ascorbic acid and CTAB," Colloids and Surfaces A: Physicochemical and Engineering Aspects, vol. 439, pp. 167-175, Dec. 2013. https://doi.org/10.1016/j.colsurfa.2013.03.003

[38] S. Vihodceva and S. Kukle, "Natural Textile Surface Modification Using Sol-Gel Technique," Material Science, vol. 6, pp. 6-11, 2011. 
[39] S. Vihodceva and S. Kukle, "Thin Coatings on the Raw Cotton Textile Deposited by the Sol-Gel Method," Material Science, vol. 7, pp. 69-73, 2012.

[40] S. Vihodceva and S. Kukle, "Cotton Fabric Surface Modification by SolGel Deposition of ZnO Thin Films," IOP Conference Series: Materials Science and Engineering, vol. 38, p. 012022, Aug. 2012. https://doi. org/10.1088/1757-899x/38/1/012022

[41] S. Vihodceva and S. Kukle, "Cotton textile surface investigation before and after deposition of the ZnO coating by sol-gel method," Journal of Nano- and Electronic Physics, vol. 5, no. 1, pp. 1-5, 2013.

[42] S. Vihodceva and S. Kukle, "Improvement of UV Protection Properties of the Textile from Natural Fibres by the Sol-gel Method," IOP Conference Series: Materials Science and Engineering, vol. 49, p. 012022, Dec. 2013. https://doi.org/10.1088/1757-899x/49/1/012022

[43] S. Vihodceva, S. Kukle, and J. Bitenieks, "Durable hydrophobic sol-gel finishing for textiles," IOP Conference Series: Materials Science and Engineering, vol. 77, p. 012023, Mar. 2015. https://doi. org/10.1088/1757-899x/77/1/012023

[44] S. Vihodceva, S. Kukle, and O. Muter, "Antimicrobial Properties of the Modified Cotton Textiles by the Sol-Gel Technology," Advanced Materials Research, vol. 1117, pp. 213-216, Jul. 2015. https://doi.org/10.4028/www. scientific.net/amr.1117.213

[45] Z. Zelca, S.Vihodceva, and S. Kukle, "Sol-gel coating processing optimization for natural fibres," Proceedings of the Estonian Academy of Sciences, vol. 66, 4, pp. 467-472, 2017. https://doi.org/10.3176/proc.2017.4.25

[46] B. Xu and Z. Cai, "Fabrication of a superhydrophobic ZnO nanorod array film on cotton fabrics via a wet chemical route and hydrophobic modification," Applied Surface Science, vol. 254, no. 18, pp. 5899-5904, Jul. 2008. https://doi.org/10.1016/j.apsusc.2008.03.160

[47] M. J. Uddin, F. Cesano, F. Bonino, S. Bordiga, G. Spoto, D. Scarano, and A. Zecchina, "Photoactive $\mathrm{TiO}_{2}$ films on cellulose fibres: synthesis and characterization," Journal of Photochemistry and Photobiology A: Chemistry, vol. 189, no. 2-3, pp. 286-294, Jun. 2007. https://doi.org/10.1016/j. jphotochem.2007.02.015

[48] Y. Kotani, A. Matsuda, M. Tatsumisago, T. Minami, T. Umezawa, and T. Kogure, "Formation of anatase nanocrystals in sol-gel derived $\mathrm{TiO}_{2}$ $\mathrm{SiO}_{2}$ thin films with hot water treatment," Journal of Sol-Gel Science and Technology, vol. 19, no. 1-3, pp. 585-588, 2000. https://doi. org/10.1023/A:1008709210723

[49] E. Pakdel and W. A. Daoud, "Self-cleaning cotton functionalized with $\mathrm{TiO}_{2} / \mathrm{SiO}_{2}$ : Focus on the role of silica," Journal of Colloid and Interface Science, vol. 401, pp. 1-7, Jul. 2013. https://doi.org/10.1016/j. jcis.2013.03.016

[50] V. Mečnika, M. Hoerr, A. Schwarz, and I. Krieviņš, "Smart textiles for healthcare: applications and technologies," In Proc. 7th International 
Scientific Conference "Rural Environment. Education. Personality", 2014, pp. 7-8.

[51] V. Etacheri, C. Di Valentin, J. Schneider, D. Bahnemann, and S. C. Pillai, "Visible-light activation of TiO2 photocatalysts: Advances in theory and experiments," Journal of Photochemistry and Photobiology C: Photochemistry Reviews, vol. 25, pp. 1-29, Dec. 2015. https://doi.org/10.1016/j. jphotochemrev.2015.08.003

[52] J. Wen, X. Li, W. Liu, Y. Fang, J. Xie, and Y. Xu, "Photocatalysis fundamentals and surface modification of TiO2 nanomaterials," Chinese Journal of Catalysis, vol. 36, no. 12, pp. 2049-2070, Dec. 2015. https://doi. org/10.1016/s1872-2067(15)60999-8

[53] J. Zhang, P. Zhou, J. Liu, and J. Yu, "New understanding of the difference of photocatalytic activity among anatase, rutile and brookite $\mathrm{TiO}_{2}$," Physical Chemistry Chemical Physics, vol. 16, no. 38, pp. 20382-20386, Aug. 2014. http://dx.doi.org/10.1039/C4CP02201G

[54] P. Papadopoulos, L. Mammen, X. Deng, D. Vollmer, and H.-J. Butt, "How superhydrophobicity breaks down," Proceedings of the National Academy of Sciences, vol. 110, no. 9, pp. 3254-3258, Feb. 2013. https://doi. org/10.1073/pnas.1218673110

[55] R. Eglītis and G. Mežinskis, "Comparison of treatments of a cotton fabric modified with a low-temperature $\mathrm{TiO}_{2}$ coating," Proceedings of the Estonian Academy of Sciences, vol. 66, no. 4, p. 473, 2017. https://doi. org/10.3176/proc.2017.4.21

Raivis Eglītis, Bc. sc. ing. (2016. g.), Rīgas Tehniskās universitātes Materiālzinātnes un lietišşāàs ķīmijas fakultātes Silikātu materiālu institūta zinātniskais asistents. Viṇa zinātniskās intereses saistītas ar pusvadītāju materiālu fotokatalītiskās aktivitātes pētījumiem, kā arī ar eksperimentālo datu lietojumu matemātiskai simulācijai, nolūkā optimizēt eksperimentālo datu interpretāciju.

E-pasts: raivis.eglitis_1@rtu.lv

ORCID: 0000-0002-6134-2624

Gundars Mežinskis, Dr. habil. sc. ing. (1998. g.), Rīgas Tehniskās universitātes profesors (2000. g.), RTU Silikātu materiālu institūta direktors (2000. g.) un Silikātu, augsttemperatūras un neorganisko nanomateriālu tehnoloǵijas katedras vadītājs (2007. g.). Viṇš ir 248 zinātnisko publikāciju autors, kā arī daudzu bakalaura, maǵistra un doktora disertāciju zinātniskais vadītājs.

E-pasts: gundars.mezinskis@rtu.lv

ORCID: 0000-0002-6030-4247

Ieva Buiķe, Mg. sc. ing. (2014. g.), Rīgas Tehniskās universitātes Silikātu, augsttemperatūras un neorganisko nanomateriālu tehnoloǵijas katedras doktorante. Viṇas interešu lokā ietilpst tekstilmateriālu modifikācija ar oksīdu nanodaḷiņām un sola-gēla tehnoloǵijas izmantošana plāno kārtiṇu ieguvei.

E-pasts: ieva.buike@gmail.com 


\section{Self-Cleaning Fabrics: What Are They and How Are They Used?}

Keywords: self-cleaning fabrics, sol-gel method, $\mathrm{TiO}_{2}, \mathrm{ZnO}$.

Self-cleaning fabrics are textile materials, which under the influence of various external environmental factors have the ability to rid their surface from various contaminants. Such fabrics make it possible to reduce water and energy consumption associated with washing clothes, to reduce the risk of infections due to their biocidal properties, and to protect people from UV radiation. In addition, such fabrics would also be more difficult to wet. This would reduce the possibility of wet clothes in damp climates. Such effects by self-cleaning fabrics could be achieved through mechanisms of photocatalysis and superhydrophobicity. To develop textiles with above mentioned properties, the most suitable approach is the deposition of coatings formed by $\mathrm{ZnO}$ and $\mathrm{TiO}_{2}$ nanoparticles. In turn, the sol-gel method should be used to obtain coatings. This would make it possible to create homogeneous coatings at temperatures that organic materials can withstand. Institute of Design Technologies, Riga Technical University, has been working on the development of such fabrics since 2011. The research in the field of such coatings at the Institute of Silicate Materials, Riga Technical University, has been performed since 2016. Thanks to decades long research in sol-gel technology and nanostructured coatings, the development of commercially available technologies for cotton fabrics has been successfully launched at the Institute of Silicate Materials. 